\title{
Effects of toll road construction on local road projects in Indonesia
}

\author{
I. G. Ayu Andani \\ University of Twente, the Netherlands; \\ Institut Teknologi Bandung, Indonesia \\ i.g.a.andani@utwente.nl \\ ayuandani@sappk.itb.ac.id

\section{Karst Geurs} \\ Center for Transport Studies, University of \\ Twente, the Netherlands \\ k.t.geurs@utwente.nl
}

\author{
Lissy La Paix Puello \\ University of Twente, the Netherlands \\ I.c.lapaixpuello@utwente.nl
}

\begin{abstract}
This study investigates the extent to which the construction of national toll roads in the Jakarta-Bandung region in Indonesia induces the development of local road projects nearby. In doing so, we disentangle the direct and indirect supply effects by considering the year of construction and urban development, respectively. We formulate four binary logit models to examine the direct and indirect relationships between toll road construction and local road projects. The dataset comprises 94 road projects planned or carried out between 2004 and 2016. We conduct interviews with local officials in the Jakarta-Bandung area to obtain data on the projects' decision-making processes. Our modelling results show that existing and planned toll roads induce the development of local road projects both directly and indirectly. Local road projects tend to be developed in anticipation of the opening of a toll road. The changes in residential area and population around the toll roads also induce local road construction.
\end{abstract}

Keywords: Toll road, local roads, decentralization, direct effect, indirect effect

\section{Article history:}

Received: June 21, 2017

Received in revised form:

August 16, 2018

Accepted: December 18, 2018

Available online: March 11,

2019

\section{Introduction}

Major road infrastructure investments can have a variety of impacts. Policy makers and planners often advocate road investments to stimulate local economic and regional growth, although academic evidence indicates that political and institutional conditions are also necessary conditions for economic development (Banister \& Berechman, 2001; Forslund \& Johansson, 1995). It is well known from the literature that construction of new major roads or expansions of existing road capacity may induce travel demand and new road investments. A study on state highway expansions in the United States reveals significant induced demand and induced investment effects. It shows that US counties cope with the

Copyright 2019 I. G. Ayu Andani, Lissy La Paix Puello, Karst Geurs

http://dx.doi.org/10.5198/jtlu.2019.1258

ISSN: 1938-7849 | Licensed under the Creative Commons Attribution - Noncommercial License 4.0

The Journal of Transport and Land Use is the official journal of the World Society for Transport and Land Use (WSTLUR) and is published and sponsored by the University of Minnesota Center for Transportation Studies. 
increasing travel demand and congestion by adding more capacity (Cervero \& Hansen, 2002), although the provision of new roads is unlikely to relieve congestion (Downs, 2000; Duranton \& Turner, 2011). Expansion of congested roads most likely will trigger drivers to change route, time of travel and travel mode to exploit the new capacity, thereby generating similar levels of congestion.

The literature on induced investments has focused on major road investments in developed countries. There is a need for a better understanding of how national road infrastructure projects induce local road projects which affect the transport and accessibility impacts of the investments. As the authors' aware, no study has investigated the relationship between national road investments and the decisionmaking for local road projects. It is particularly relevant in developing countries with decentralized government systems such as Indonesia, where the different levels of governance share the responsibility for the transport networks.

Indonesias central government authorizes investments in national roads, e.g., toll roads, while the lower-tier levels of government control local road projects. Local roads connect districts and communities, carry low traffic volumes and have the lowest speed limit. Among other things, decentralization aims to increase local government responsiveness and improve infrastructure services at the local level. Coordination, however, has become a major concern to increase the benefits of transport investment across regions.

Several studies have examined road investment decision-making at the national level (for example, Eliasson, Börjesson, Odeck, \& Welde, 2015; Fridstrom, 1999; Nellthorp \& Mackie, 2000; Nilsson, 1991; Nyborg, 1998; Odeck, 1996, 2010). However, to our knowledge, no study has linked national road investments to decision-making on local road investments. Yet, local roads are required to link new urban developments with major roads and thereby improve regional accessibility.

Studies in both developed and developing countries show that investments in major roads stimulate urban spatial expansion and residential growth. Land-use change and population density tend to be intensified in the distance close to the roads (see, for example, Aljoufie, Zuidgeest, Brussel, \& van Maarseveen, 2013; Baum-Snow, 2007; Chi, 2010; Ji et al., 2014).

Furthermore, Cervero and Hansen (2002) observed that changes in population also influence the addition of highway lane miles in California. They argued that road investments not only have stimulated travel demands, but also responded to it, as they found both significant induced-demand and induced-investment effects.

This paper aims to examine the extent to which the construction of national toll road projects induces local road investments in Indonesia, taking urban development and local decision-making into account. Note that all new national toll roads in Indonesia are considered as "major roads;" "toll road" can therefore often be read as interchangeable with "major road" throughout this paper. The added value of this paper is twofold: (1) the combination of statistical analysis, with spatially detailed data to perform a robust predictive model; and (2) the use of high temporal and spatial resolution to analyze ex-post toll cases in developing countries.

This paper is structured as follows. After this introduction, Section 2 provides the background for this study, including a review of the direct and indirect effects of major road construction as well as the decision-making involved in local road projects. Section 3 explains the methodology, followed by the description of the study area and data employed in this study in Sections 4 and 5. Section 6 presents the results of the analysis and discusses the results. The final section contains concluding remarks and suggestions for further research. 


\section{Theoretical framework}

In theory, major investments in transport infrastructure have both direct and indirect effects on local transport systems, and one of the aims of this study was to identify these direct and indirect effects. As neither direct nor indirect effects can occur without government involvement, this study therefore also considers the decision-making process for local road investment. Figure 1 presents the relationship between direct and indirect effects of major-road construction on local road projects, which will be further elaborated in this section.

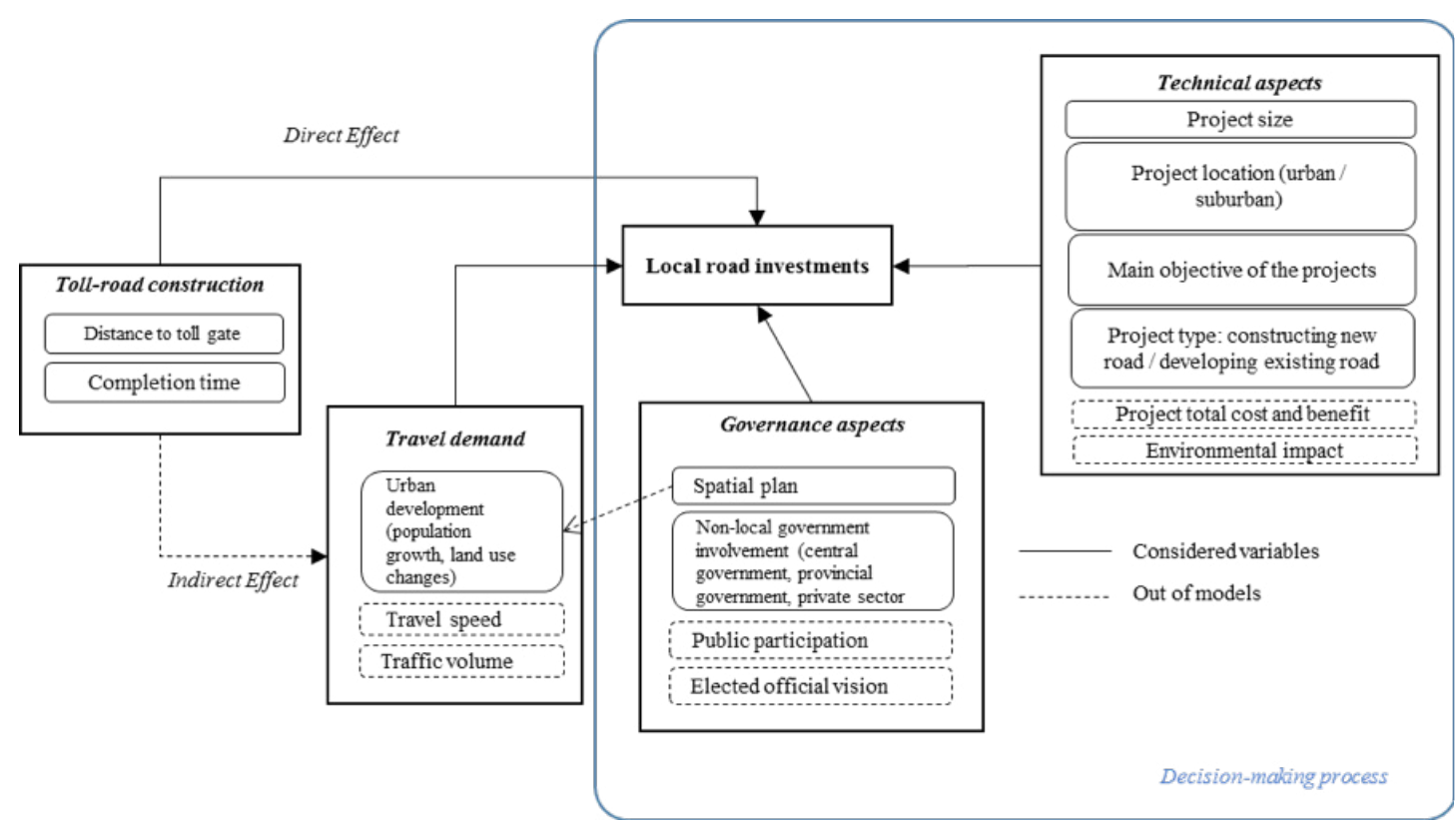

Figure 1. Conceptual framework

\subsection{Direct effects of major road construction}

Direct effects of major transport investments, such as a redistribution of traffic and congestion effects are directly related to the investments and happen directly after opening. Some direct effects of major new infrastructure on local road infrastructure occur in support of the construction of the former, meaning that there is a direct connection between the two. For example, a toll road cannot be operated without motorway links that connect the toll road with existing local roads. The construction of a major new road, therefore, has to be supported by the construction of these links and possibly also widening and other improvements of existing roads given the expected increased traffic flow. This infrastructure dependency is a unidirectional relationship; one type of infrastructure depends on another type of infrastructure (Rinaldi, Peerenboom, \& Kelly, 2001).

According to the US Council on Environmental Quality (Avin, Cervero, Moore, \& Dorney, 2007), new infrastructure can also have direct effects on land use, which also occur almost instantly. For instance, the land taken during the construction of a major road (because the project could not be started without land-use changes). Boarnet (1996) studied the direct effect of transport investment on economic activity and described it as the influence exerted in the vicinity of the new road. 


\subsection{Indirect effects of major road construction}

New major road infrastructure can have indirect effects on local road projects as well, if it induces landuse changes or other spill-over effects. Indirect effects take place later, more slowly and have a wider spatial influence (spatial spill-overs) than direct effects. The US Council of Environmental Quality (as cited by Avin et al., 2007) described indirect effects as being caused by a particular action, later in time or farther in the distance yet still reasonably foreseeable. In the literature, indirect effects are also referred to as external or secondary effects, induced effects, distributive effects or cumulative effects. The use of this terminology mostly depends on the research field.

The indirect effect occurs as the result of many interacting factors. For instance, as the completion of a major road project shortens travel time, it encourages firms and workers to move to the suburbs, where the land price tends to be lower. Therefore, more residential development follows. This urbanization will further induce travel demand and increase the need for local transport investments. In this example, the term "indirect effects" refers to the increased motivation to invest in local roads after the completion of a major road. Generally speaking, it may arise as a result of the growth in travel demand due to the changing land use, growing population, traffic congestion as well as damage to existing roads because of the heavier traffic.

Several studies in developing countries have indicated that changes in both built-up area and population tend to be at the proximity to highways (see, for example, Chi, 2010; Ji et al., 2014). Ghani, Goswami, and Kerr (2012), for instance, found that manufacturers located more than $10 \mathrm{~km}$ from the highway project in India benefit less than manufacturers situated closer to the project. However, to our knowledge, no study has examined the effect of urban development on transport infrastructure construction in developing countries yet. Our study therefore specifically also takes urban development into account in the identification of the effect of toll road construction on local road projects.

In addition, it is important to note that urbanization differs across rural, suburban and urban areas (Chi, 2010). Goode and Hastings (1989) pointed out that the proximity to highway access has a positive effect on industrial locations in small metropolitan counties, but not in non-metropolitan counties. Rephann and Isserman (1994) described similar findings and concluded that highway construction benefits urbanized areas (defined as areas with a population of more than 25,000) more than rural areas. Fridstrom and Elvik (1997) and Eliasson et al. (2015) also took this difference into account in their studies.

\subsection{Decision-making on local road projects}

Decision-making on local road projects by local governments is influenced by technical and governance aspects, as highlighted in Figure 1.

\subsubsection{Technical aspects}

The characteristics of local road projects and the resulting benefits affect the priorities in local governmental decision-making. A local government may prefer the construction of a longer link with a greater service area (Eliasson et al., 2015; Fridstrom, 1999). Another critical factor is the nature of the road project, for instance, whether it concerns the construction of a new road or not (Fridstrom \& Elvik, 1997). Cervero and Hansen (2002) found that many urbanized regions carried out improvements to their current road networks rather than the construction of new roads.

Several studies have focused on the role of cost-benefit analysis (CBA) in decision-making on major roads. The CBA typically includes accessibility benefits, changes in externalities (emission, congestion or noise) investment cost and transport-related revenues (Eliasson et al., 2015). Eliasson and Lundberg 
(2012) found, for example, that CBA played a role in investment selection in Sweden and forced investment design to be more cost-efficient. Studies in Norway (Odeck, 2010) and Sweden (Nilsson, 1991) show that the decision-makers do not select projects primarily based on outcomes of CBA but focus on specific benefits such as reducing travel time, minimizing accidents rates and encouraging regional developments. Mouter (2017) shows that Dutch politicians also use CBA in an opportunistic and symbolic way. In most countries, including Indonesia, cost-benefit analyses are used for the planning of major infrastructure rather than for local infrastructure, however. Therefore, to determine decision-making in local projects, we did not take into account any variables related to CBA, but directly incorporated the characteristics of the project in the model.

\subsubsection{Governance aspects}

It is often assumed that decision-making is based on a rational approach, in which decision-makers consider all possible ways to achieve an objective. A major constraint for such a rational approach is the high degree of complexity and uncertainty which characterizes the field of infrastructure. It is hard to commit to many resources for a long period without having the certainty of demand or potential effects. Also, this complexity includes the involvement of various stakeholders with different, potentially competing interests; they will all try to influence the decision-makers. As a result, decisions about infrastructure development often rely on members of parliament or other elected officials (see Nyborg, 1998; Odeck, 1996).

The class of the road plays a role as well since this relates not only to the size of the project but also to its level of authorization. Nilsson (1991) considered local, national and European roads in his study of the ranking of road schemes in Sweden; his findings may also apply to the case of a country's decentralized infrastructure provision, such as in Indonesia.

Local road projects, as well as other local programs, are linked to the development goals of both local and national government (stated in strategic plans) and the views of elected officials. This decisionmaking flow is a conventional top-down process. Nevertheless, local investments can also come about through community aspiration and participation. The process usually includes discussions involving various stakeholders, such as parliament members, community groups, academia and the private sector.

However, the final decisions are still in the hands of public bureaucrats. The Ministry of Public Works, for example, is in charge of planning and construction of road networks as well as of water and irrigation systems. Both its annual action plan and five-year strategic plan are based on the municipalities' strategic and spatial plans. This kind of decision-making relies on planning requirements and permission. Fridstrom and Elvik (1997) also found that the status of the projects (planned and approved by Parliament but not yet started or already begun) is essential in the prioritization of road projects.

Authorization also largely corresponds to the source of the investments. Central transfers are the primary source of revenue (90\%) for local government in Indonesia. Local government investment also

comes from other sources, namely local revenue, external and provincial grants and additional forms of income permitted by law, such as cooperation with the private sector.

As the brief preceding analysis shows, toll road construction can stimulate local road investment directly or indirectly. We decided to take a modelling approach to investigate this further and to adopt factors that previous studies found to be significant in explaining the effects of the construction of highways. This paper fills the gap in terms of how the construction of major roads could affect local roads construction. 


\section{$3 \quad$ Methodology}

We applied a standard binary logit model to assess the probability of local road project development. To test the hypothesis that national toll roads induce the construction of local road projects, directly and indirectly, we formulated four models and composed each model with different independent variables. The dependent variable of all modes is binary of the presence of local road projects. Meanwhile, the independent variables are including the toll road characteristics, urban development and decision-making factors.

The first model is the base model, which attempts to describe the decision-making for local road projects. This model is composed of several independent variables related to investment cost, the length of the road project, location, road type and government involvement. The second model is the direct effect model, in which toll road construction is assumed to affect local road projects directly. The second model is an extension of the base model. It includes variables of the year gap between the construction year of local road projects and the opening year of the closest toll road gate, and the distance between toll gates and the road project. The third model is the indirect effect model, which assumes that urban development triggers local roads construction. Thus, the third model improves the base model by including variables of residential and industrial land-use changes, and population change. Finally, the fourth model is the composite model, which combines the direct and indirect effect models.

We created three datasets with square cell sizes of $100 \mathrm{~m}^{2}, 500 \mathrm{~m}^{2}$ and $1 \mathrm{~km}^{2}$ with $6,098,1,224$ and 631 observations, respectively. Using a smaller cell size enabled us to incorporate small projects as well. Larger cells, on the other hand, allow easy identification of changes in urban development. A further selection of the dataset then was done on the basis of land use and population changes data, which left us with 5,994, 1,202 and 619 observations in the three datasets. These numbers are sufficiently large for statistical analysis.

The observed cells showed in Figure 2. Blue cells containing the link of the projects are treated as an observation ${ }^{1}$ in the model. The probability of a cell to have a local road project (i) or not $(j)$ can be formulated as follows (Ben-Akiva \& Lerman, 1985):

$$
P_{(i)}=\frac{e^{\mu \beta^{\prime} x_{i n}}}{e^{\mu \beta^{\prime} x_{i n}}+e^{\mu \beta^{\prime} x_{j n}}}
$$

Here, $\beta$ ' is the vector of the unknown parameters, $x$ is the vector of attributes, $n$ is the number of cell and $\mu$ is a positive scale parameter. The value of $\mu$ is fixed to 1 , as in any binary or multinomial logit model (Train, 2009).

The logit model has two alternatives: "local project" and "national project." Then, the model estimates the probability of having either a local or national project in the cell after controlling by other toll related variables. The general objective of this study examines the extent to which the construction of national toll road projects induces local road investments, with a case study in Indonesia. These projects are linked to the construction of the toll by other variables, such as "year gap" and "distance to toll gate." Via the logit model, we can investigate how the existence of the toll affects the construction of the projects.

${ }^{1}$ As the cells (observations) are derived from the road projects itself, each cell contains the values of the variable related to the project on the cell. Also because of the derivation, several cells could have the same value of the analyzed variable. 


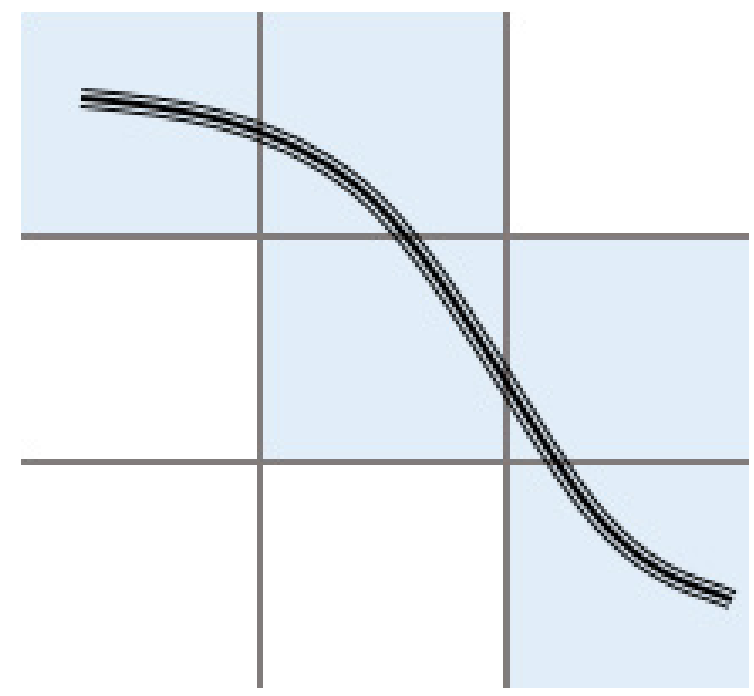

Figure 2. Example of observed cells and the project's link

We chose the parsimonious (minimum number of predictor variables with great explanatory predictive power) model as the preferred model and used those variables that had a confidence level of $95 \%$ in the model. The estimation of arc (direct) elasticities with respect to independent variables are also of interest in this study, to show the relationship between a percent change in independent variables and the percent change in the probability of realization or funding of local road projects. We modified specific continuous variables by $10 \%$, keeping other variables constant and calculated the average arc elasticity with the following formula (Bierlaire, 2017),

$$
\bar{E}_{X_{i n k}}^{P_{n}(i)}=\frac{1}{N} \sum_{n=1}^{N} \frac{\Delta P_{n}(i)}{\Delta X_{i n k}} \frac{X_{i n k}}{P_{n}(i)}
$$

Here, $X_{i n k}$ is the value of each independent variable $k$ in each observation $n ; \Delta X_{i n k}$ is the value of the change in variable $k$ after the modification. $P_{n}(i)$ is the probability of having local road projects and $\Delta P_{n}(i)$ is the change in the probability after the increment of $x$.

\section{$4 \quad$ Study area}

In Indonesia, public road infrastructure is managed in a decentralized administration and followed a hierarchical system. According to its status and authority, public roads can be classified to, (1) national roads, (2) provincial roads, (3) regency roads, (4) municipal roads and (5) village roads. In this study, the last three are simplified as local roads.

A state-owned enterprise of Indonesia manages most toll roads. On the other hand, local roads are authorized by the lowest level of government (regency or municipality). The construction of the roads should follow this hierarchy. For instance, municipal (local) roads are to some extent not allowed to link to national roads directly.

Toll road and local road construction have different funding sources. Although toll roads require larger investments than local roads, they also have a higher rate of return, as users pay a fee to use a toll road, but do not pay for the use of local roads. Therefore, the private sector prefers to invest in toll roads rather than in local roads. 
Our study area covers 13 municipalities in the corridor of Jakarta and Bandung as shown in Figure 3. The name "Cipularang" is a contraction of "Cikampek, Purwakarta and Padalarang." This toll road connects Jakarta and Bandung by connecting the Jakarta-Cikampek toll road and the Padalarang-Cileunyi (Padaleunyi) toll road (of which the Pasteur toll road in Bandung is also a part). The Cipularang toll road has five gates; three gates are located in the West Bandung Regency, and the other two are in the Purwakarta Regency. There are many toll roads in this area, such as the Jakarta-Cikampek toll road (built in 1986), the Jagorawi toll road (built in 1983) and the Cikampek-Palimanan toll road (built in 2015). Several more toll roads are planned for construction in the study area, such as toll road sections that connect Bogor and Cianjur.

\section{$5 \quad$ Data}

Time series of local road projects data are difficult to obtain as data on local road projects is only available in each municipality. We, therefore, based this study on the limited available data from local municipalities, GIS data for the period 2000 to 2013 and semi-structured interviews with thirteen local officials from each municipality in the Jakarta-Bandung region. During the interviews, local officials added or eliminated local road projects from our dataset, if they did or did not consider the projects to be connected with the toll road (in terms of traffic). The interviews also explored the decision-making of the projects, specifically 1) whether the construction of the toll road was part of the local road project decision, 2) the main motivation for the investment (connecting newly developed areas, reducing travel time or increasing traffic safety) and 3) the involvement of non-local government.

This data collection led to a selection of 96 projects (depicted in Figure 3), of which $72 \%$ had been completed, and the remainder were at the time of data collection (mid-2016) in the planning stage (with funding secured) or under construction. The projects included in this study are projects which are aimed to improve the capacity of the current network or improve connectivity to a toll road. Maintenance projects are excluded from this study. All were located within a distance of $18 \mathrm{~km}$ to toll road access and carried out between 2000 and 2016. In our study, local projects are oversampled (81\%) relative to toll roads, and 19\% are non-local projects (national and provincial). Non-local road projects were included to examine characteristic differences between local and non-local road projects. Tables 1 and 2 describe the variables used in this research. A detailed explanation of the variables follows in the sections below. 


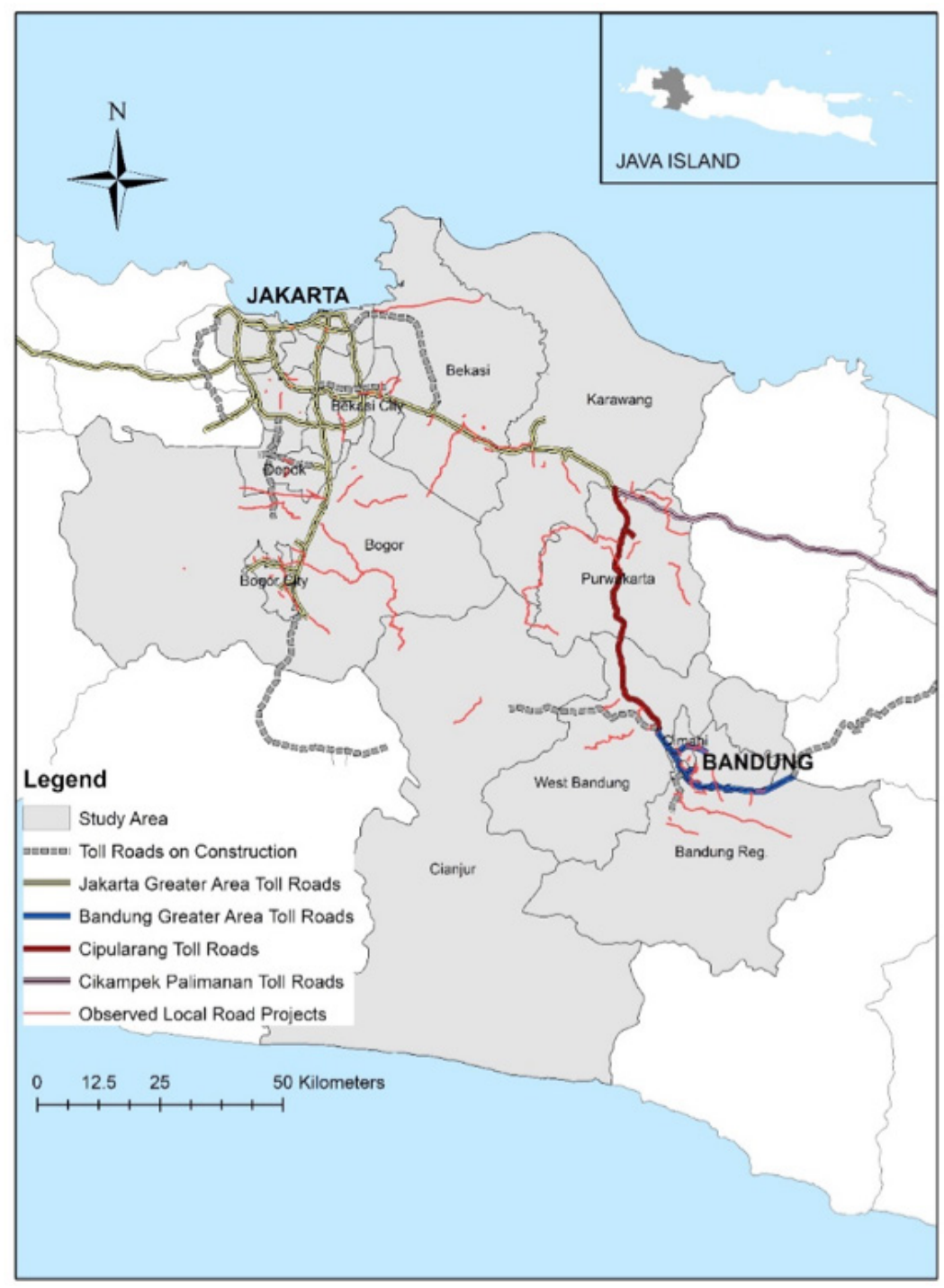

Figure 3. Case study area

\subsection{Direct effect variables}

We investigated the direct effect of toll road construction with two variables of distance to toll gates and year gap between the construction year of the local road project and the opening year of the closest toll road gate. Distance to the toll gates is the shortest Euclidean distance from the road to the toll gates (variable no. 3 in Table 1). The average of closest distance between non-local (national or provincial) road projects and the toll gate is $2.9 \mathrm{~km}$. On the other hand, $3.4 \mathrm{~km}$ is the average of closest distance between all projects and the toll gate. National and provincial roads tend to locate within proximity to the toll gates. We distinguished three categories of the project's proximity to the toll gates: long (more than 3.4 $\mathrm{km}$ ), medium (2.9 to $3.4 \mathrm{~km}$ ) and short distance (less than $2.9 \mathrm{~km}$ ). We used these categories as binary input for the model (variables No. 1-3 in Table 2).

The variable "year gap" (variables No. 1 and 2 in Table 1) is obtained by subtracting the (start) construction year of the project and the opening year of the closest toll gate, either of an already existing toll road or one that was planned. Some road links consisted of several sections with different years of 
construction; in that case, they were considered different projects. Subtracting the year of the toll gate's opening from the year of the local project's construction beginning yields positive and negative values. As it is more convenient and enables a more precise interpretation of the results, we separated this variable into two variables, one with a positive value and one with a negative value. Positive year gap means that a local road is constructed after or at the same time the toll gate opened. On the contrary, the negative year gap means a local road started to construct before the opening of the closest toll gate and finished before, at the same time or after the opening of the toll gate.

\subsection{Indirect effect variables}

Urban development is represented by variables of residential land use, industrial land use and population change. Land-use change data of the thirteen municipalities is available in the year 2004 and 2013. We converted the parcel-level land-use data to a raster format. There is some remaining error, as a result of the manual digitization and the lower level of accuracy associated with earlier mapmaking. The case study area covers approximately $15,250 \mathrm{~km}^{2}$. We partitioned it into a grid of cells of $10 \mathrm{~m}$ by $10 \mathrm{~m}$ and assigned a land-use type to each cell according to its dominant land use.

Between 2004 and 2013, the residential land use increased by $2.5 \%$ and the industrial land use by $1 \%$. As Figure 4 shows, emerging industrial development tend to be located along the toll road, especially in the municipalities of Karawang and Bekasi. It is likely that the previous land use was rice field or plantation area since this type of land use decreased by $4.3 \%$.

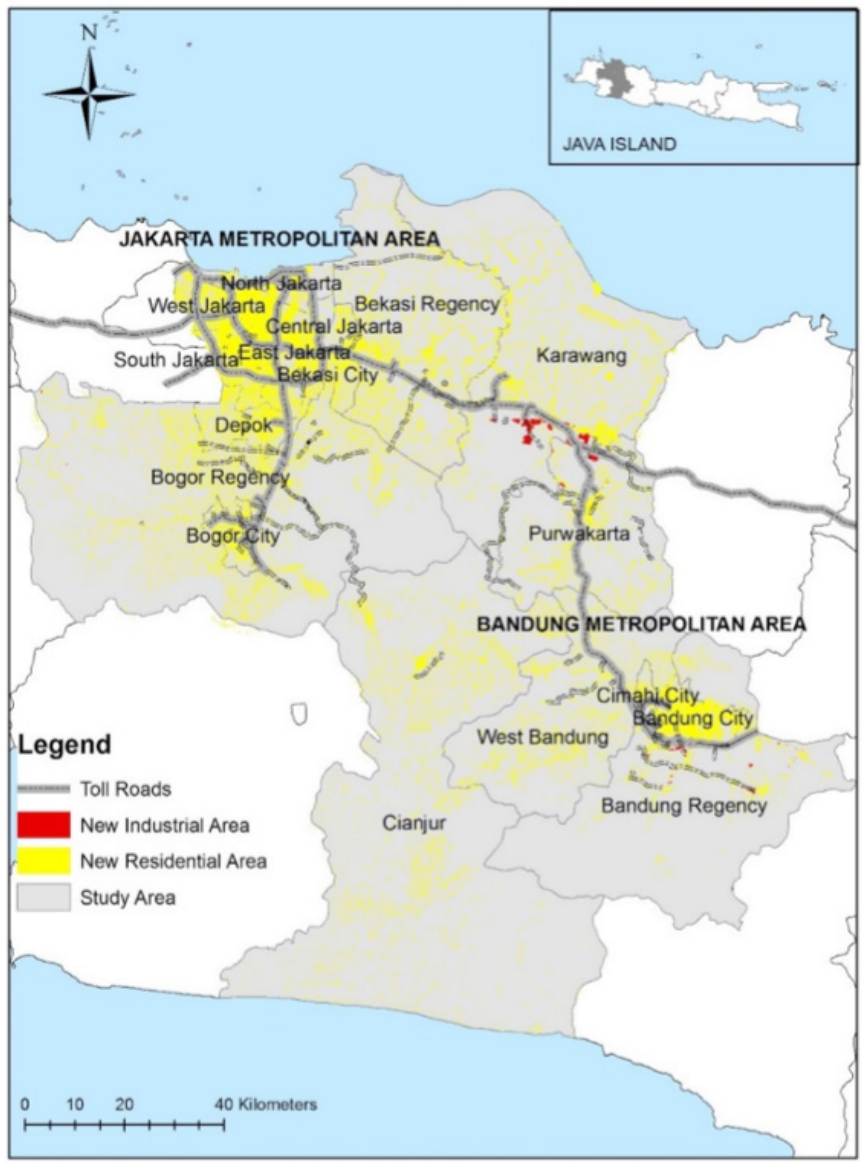

Figure 4. Residential and industrial area developments (2004-2013) 
Furthermore, we used population change data for two periods in the models, namely for the period 2000 to 2010 and 2010 to 2015 . This data is in the form of a raster with $100-\mathrm{m}$ square cells. The usage of population change in this study is to specifically address population growth on decisions to build or expand local roads. Using three time points of population number in the model could raise multicollinearity. Moreover, still, we expect that variables of population and residential land-use changes to be correlated to each other. However, we have found no correlation between both variables in this case. Therefore, they are incorporated in the model.

\subsection{Decision-making process variables}

As described earlier, we conducted semi-structured interviews to collect project characteristics and related decision-making factors. We then converted these variables into binary data. We gathered other project characteristics from various sources. Data on project length (in kilometers) and construction year were collected from the local government action plan documents and local electronic procurement service websites. We also checked if the projects were already included in the local long-term spatial plan (20 years). The term of these spatial plan varies; for instance, the spatial plan of Bandung City is for the period 2011-2031, whereas Jakarta's is for the period 2010-2030. These variables were also entered into the models as binary data.

Our models take the spatial distribution into account as well (whether a project is located in an urban or suburban area). We followed the distinction made by the West Java Provincial Government on the urban, suburban and rural areas, according to the population density and the proportion of built-up area (WJP-MDM, 2013). The whole area of Jakarta is characterized as an urban area (more than 500 people per $\mathrm{km}^{2}$ ). Tables 1 and 2 present the descriptions of the explanatory variables. 
Table 1. Description of quantitative variables

\begin{tabular}{|c|c|c|c|c|c|c|c|c|}
\hline \multirow[b]{2}{*}{ No. } & \multirow[b]{2}{*}{ Variables } & \multirow[b]{2}{*}{ Definition } & \multicolumn{3}{|c|}{ Mean } & \multirow[b]{2}{*}{ Min } & \multirow[b]{2}{*}{$\operatorname{Max}$} & \multirow[b]{2}{*}{ St. dev } \\
\hline & & & $\begin{array}{l}\text { Non- } \\
\text { local }\end{array}$ & Local & $\begin{array}{l}\text { All } \\
\text { proj- } \\
\text { ects }\end{array}$ & & & \\
\hline \multicolumn{9}{|c|}{ Direct effect model } \\
\hline 1 & YEARGAP_POS & $\begin{array}{l}\text { Positive year gap between toll } \\
\text { road construction and project }\end{array}$ & 3.6 & 10.6 & 13.2 & 0.0 & 39.0 & 10.9 \\
\hline 2 & YEARGAP_NEG & $\begin{array}{l}\text { Negative year gap between toll } \\
\text { road construction and project }\end{array}$ & 0.8 & 0.4 & 0.4 & 0.0 & 14.0 & 1.9 \\
\hline 3 & DISTANCE & $\begin{array}{l}\text { The shortest distance between } \\
\text { toll gate and project link (in } \\
\text { kilometer) }\end{array}$ & 2.9 & 3.7 & 4.0 & 0.1 & 18.5 & 3.7 \\
\hline \multicolumn{9}{|c|}{ Indirect effect model } \\
\hline 4 & RESIDENTIAL & $\begin{array}{l}\text { Change in residential land use in } \\
\text { each cell (in hectares) }\end{array}$ & 0.0 & 0.0 & 0.0 & -1.0 & 1.0 & 0.3 \\
\hline 5 & INDUSTRIAL & $\begin{array}{l}\text { Change in industrial land use in } \\
\text { each cell (in hectares) }\end{array}$ & 0.0 & 0.0 & 0.0 & -1.0 & 1.0 & 0.2 \\
\hline 6 & POPCHANGE1015 & $\begin{array}{l}\text { Change in population number } \\
\text { in each cell, between } 2010 \text { and } \\
2015\end{array}$ & 6.7 & 10.3 & 7.3 & 0.0 & 120.0 & 10.9 \\
\hline 7 & POPCHANGE0010 & $\begin{array}{l}\text { Change in population number } \\
\text { in each cell, between } 2000 \text { and } \\
2010\end{array}$ & 14.5 & 22.8 & 15.7 & -109.0 & 579.0 & 42.9 \\
\hline \multicolumn{9}{|c|}{ Decision-making (base model) } \\
\hline 8 & COSTPERKM & $\begin{array}{l}\text { Non-discounted investment } \\
\text { costs per kilometer of road (in } \\
10^{9} \text { Indonesian Rupiah) }\end{array}$ & 17.0 & 13.4 & 16.5 & 0.0 & $1,213.6$ & 74.0 \\
\hline 9 & LENGTH & $\begin{array}{l}\text { Length of a road project (in } \\
\text { kilometers) }\end{array}$ & 21.2 & 9.4 & 19.5 & 0.1 & 51.3 & 17.6 \\
\hline
\end{tabular}


Table 2. Description of binary variables

\begin{tabular}{|c|c|c|c|c|c|c|}
\hline \multirow[b]{2}{*}{ No. } & \multirow[b]{2}{*}{ Variables } & \multirow[b]{2}{*}{ Definition } & \multirow[b]{2}{*}{ Category } & \multicolumn{3}{|c|}{ Percentage } \\
\hline & & & & Non-local & Local & $\begin{array}{c}\text { All } \\
\text { projects }\end{array}$ \\
\hline \multicolumn{7}{|c|}{ Direct effect model } \\
\hline \multirow[t]{2}{*}{1} & \multirow{2}{*}{$\begin{array}{l}\text { DISTANCE_ } \\
\text { SHORT }\end{array}$} & \multirow{2}{*}{$\begin{array}{l}\text { The shortest distance between toll gate and } \\
\text { project link is less than } 2.9 \mathrm{~km}\end{array}$} & 0 & $2.9 \%$ & $50.9 \%$ & $53.8 \%$ \\
\hline & & & 1 & $12.0 \%$ & $34.1 \%$ & $46.2 \%$ \\
\hline \multirow[t]{2}{*}{2} & \multirow{2}{*}{$\begin{array}{l}\text { DISTANCE_ } \\
\text { MID }\end{array}$} & \multirow{2}{*}{$\begin{array}{l}\text { The shortest distance between toll gate and } \\
\text { project link is between } 2.9 \text { and } 3.4 \mathrm{~km}\end{array}$} & 0 & $14.9 \%$ & $82.7 \%$ & $97.6 \%$ \\
\hline & & & 1 & $0.0 \%$ & $2.4 \%$ & $2.4 \%$ \\
\hline \multirow[t]{2}{*}{3} & \multirow{2}{*}{$\begin{array}{l}\text { DISTANCE_ } \\
\text { LONG }\end{array}$} & \multirow{2}{*}{$\begin{array}{l}\text { The shortest distance between toll gate and } \\
\text { project link is more than } 3.4 \mathrm{~km}\end{array}$} & 0 & $12.0 \%$ & $36.5 \%$ & $48.5 \%$ \\
\hline & & & 1 & $2.9 \%$ & $48.6 \%$ & $51.5 \%$ \\
\hline \multicolumn{7}{|c|}{ Decision-making (base model) } \\
\hline \multirow[t]{2}{*}{4} & \multirow{2}{*}{ URBAN_AREA } & \multirow[t]{2}{*}{ Urbanized areas } & 0 & $0.1 \%$ & $37.5 \%$ & $37.6 \%$ \\
\hline & & & 1 & $14.8 \%$ & $47.6 \%$ & $62.4 \%$ \\
\hline \multirow[t]{2}{*}{5} & \multirow[t]{2}{*}{ NEWROAD } & \multirow[t]{2}{*}{ The project is a new link } & 0 & $11.0 \%$ & $16.4 \%$ & $27.3 \%$ \\
\hline & & & 1 & $4.0 \%$ & $68.7 \%$ & $72.7 \%$ \\
\hline \multirow[t]{2}{*}{6} & \multirow[t]{2}{*}{ MAINROAD } & \multirow{2}{*}{$\begin{array}{l}\text { The project is part of a functional main } \\
\text { road }^{2}\end{array}$} & 0 & $0.2 \%$ & $45.8 \%$ & $45.9 \%$ \\
\hline & & & 1 & $14.8 \%$ & $39.3 \%$ & $54.1 \%$ \\
\hline \multirow[t]{2}{*}{7} & \multirow[t]{2}{*}{ TT_REDUCE } & \multirow{2}{*}{$\begin{array}{l}\text { The main aim of the project is to reduce } \\
\text { travel time }\end{array}$} & 0 & $10.4 \%$ & $21.6 \%$ & $32.0 \%$ \\
\hline & & & 1 & $4.5 \%$ & $63.5 \%$ & $68.0 \%$ \\
\hline \multirow[t]{2}{*}{8} & \multirow[t]{2}{*}{ NEWACCESS } & \multirow{2}{*}{$\begin{array}{l}\text { The main aim of the project is connecting } \\
\text { new areas }\end{array}$} & 0 & $6.7 \%$ & $67.1 \%$ & $73.8 \%$ \\
\hline & & & 1 & $8.3 \%$ & $18.0 \%$ & $26.2 \%$ \\
\hline \multirow[t]{2}{*}{9} & CENTRAL & Central government involvement in the & 0 & $7.8 \%$ & $33.1 \%$ & $40.8 \%$ \\
\hline & & project & 1 & $7.2 \%$ & $52.0 \%$ & $59.2 \%$ \\
\hline 10 & PROVINCIAL & Provincial government involvement in the & 0 & $6.2 \%$ & $63.3 \%$ & $69.6 \%$ \\
\hline & & project & 1 & $8.7 \%$ & $21.7 \%$ & $30.4 \%$ \\
\hline 11 & PRIVATE & Private sector involvement in the project & 0 & $13.3 \%$ & $64.8 \%$ & $78.1 \%$ \\
\hline & & & 1 & $1.6 \%$ & $20.2 \%$ & $21.9 \%$ \\
\hline 12 & SPATIAL_ & Projects included in local spatial plan & 0 & $3.0 \%$ & $12.8 \%$ & $15.7 \%$ \\
\hline & PLAN & & 1 & $12.0 \%$ & $72.3 \%$ & $84.3 \%$ \\
\hline
\end{tabular}

\section{$6 \quad$ Results and discussion}

\subsection{Modelling local road projects}

We tested three datasets with different geographical scales $\left(100 \mathrm{~m}^{2}, 500 \mathrm{~m}^{2}\right.$ and $1 \mathrm{~km}^{2}$ cells $)$ to select the most suitable data set. The set of $100 \mathrm{~m}^{2}$ cells and 5,994 observations yielded the best goodness of fit. We, therefore, used this dataset to model the direct and indirect effects of toll road construction on local road projects.

We estimated the direct effect model by incorporating distance to toll gates and the year gap between the construction of a local project and the construction of a toll road as variables. In the indirect effect model, we replaced the toll road construction variables with urban development variables, such as residential land use, industrial land use and population changes. The direct and indirect models were combined in the composite model to achieve better data representation.

\footnotetext{
${ }^{2}$ In the case of Indonesia, main roads are connecting primary areas which consist of main activities, such as regional industrial area, airport, regional market, harbor, airport and regional-scaled commercial area.
} 
We then generated four parsimonious models, by keeping only those parameters with $\mathrm{p}<0.05$. The p-values are used to determine the level of significance of each coefficient. Table 3 lists the results of the logit models. The parameters are estimated from the logit model. The value of the coefficient of each parameter shows the log of the odds of having a local road project with respect to the variables.

Parameters of "travel time reduction" and "new roads" were found to be correlated to each other, as well as "spatial plan" and "length of the project." Bigger projects should be planned ahead and included in the spatial as they also attract greater interest. Putting the aforementioned variables as single independent variables in the model resulted in one of the parameters could not be identified correctly (i.e., the parameter unexpectedly to be negative or insignificant). Thus, the product of those variables is incorporated into the model.

In Table 3, we can see that the direct effect model has a higher value of $\mathrm{R}^{2}(0.85)$ than the indirect effect model (0.62). Among the four models, the composite model has the highest $\mathrm{R}^{2}$ statistic and considered the most representative model. A way to ascertain the significance of adding more parameters in the model is to use a log-likelihood ratio test (LLR) and compare the final log-likelihood between the restricted model and the unrestricted model. The test statistic is:

$$
L L R=-2\left(\mathrm{~L}\left(\beta_{\mathrm{R}}\right)-\mathrm{L}\left(\beta_{\mathrm{U}}\right)\right)
$$

where $\beta_{R}$ denotes the estimated coefficients of the restricted model and $\beta_{U}$ denotes the estimated coefficients of the unrestricted model. Restricted log-likelihood $\left(L\left(\beta_{R}\right)\right)$ reflects the model estimation from the initial explanatory variables, in this case, variables included in the base model. Furthermore, unrestricted $\log$-likelihood $\left(\mathrm{L}\left(\beta_{\mathrm{U}}\right)\right)$ is the log-likelihood obtained by adding parameters to the base (restricted) model. The log-likelihood is calculated using this formula (Train, 2009):

$$
\mathrm{L}(\beta)=\sum_{n=1}^{N} \sum_{i} y_{n i} \ln \left(P_{n i}\right)
$$

where $y_{n i}=1$ if there is a local road project in the cell observed and zero otherwise and $P_{n i}$ is simply the probability of having a local project in each cell. The result of $L L R$ can then be tested against the chi-squared $\left(x^{2}\right)$ distribution with $K_{U}-K_{R}$ degrees of freedom (df), where $K_{U}$ and $K_{R}$ are the number of parameters in the restricted and unrestricted model respectively.

The bottom row in Table 3 lists the critical values of the chi-square distribution at a $95 \%$ confidence level of each model $\left(x_{0.05}^{2}\right)$. Since in all three models, $L L R>x_{0.05}^{2}$, then we can reject the null hypothesis and conclude that adding parameters of the toll road and urban development significantly improved the model. 
Table 3. Logit model results $(\mathrm{N}=5,994)$

\begin{tabular}{|c|c|c|c|c|c|c|c|c|}
\hline \multirow[t]{2}{*}{ Parameters } & \multicolumn{2}{|c|}{ Base model } & \multicolumn{2}{|c|}{ Direct effect model } & \multicolumn{2}{|c|}{$\begin{array}{c}\text { Indirect effect } \\
\text { model }\end{array}$} & \multicolumn{2}{|c|}{ Composite model } \\
\hline & Coef. & $p$ & Coef. & $p$ & Coef. & $p$ & Coef. & $p$ \\
\hline YEARGAP_POS & - & - & 0.18 & 0.00 & - & - & 0.16 & 0.00 \\
\hline YEARGAP_NEG & - & - & -1.04 & 0.00 & - & - & -1.18 & 0.00 \\
\hline DISTANCE & - & - & 0.54 & 0.01 & - & - & 0.49 & 0.01 \\
\hline DISTANCE_LONG & - & - & 6.89 & 0.00 & - & - & 7.46 & 0.00 \\
\hline RESIDENTIAL & - & - & - & - & 0.65 & 0.00 & 0.77 & 0.00 \\
\hline POPCHG1015 & - & - & - & - & 0.02 & 0.00 & 0.05 & 0.00 \\
\hline POPCHG0010_POS & - & - & - & - & - & - & 0.59 & 0.00 \\
\hline POPCHG0010_NEG & - & - & - & - & - & - & -0.51 & 0.00 \\
\hline INDUSTRIAL & - & - & - & - & 0.54 & 0.03 & - & - \\
\hline URBAN_AREA & -4.12 & 0.00 & -5.34 & 0.00 & -4.29 & 0.00 & -5.43 & 0.00 \\
\hline COSTPERKM & 0.01 & 0.00 & 0.05 & 0.00 & 0.01 & 0.00 & 0.05 & 0.00 \\
\hline CENTRAL & -1.58 & 0.00 & -8.21 & 0.00 & -1.47 & 0.00 & -8.27 & 0.00 \\
\hline PROVINCIAL & -1.72 & 0.00 & -8.59 & 0.00 & -1.75 & 0.00 & -8.86 & 0.00 \\
\hline $\begin{array}{l}\text { TTREDUCE* } \\
\text { NEWROAD }\end{array}$ & 2.14 & 0.00 & 3.71 & 0.00 & 2.23 & 0.00 & 4.27 & 0.00 \\
\hline $\begin{array}{l}\text { SPATIAL_PLAN* } \\
\text { LENGTH }\end{array}$ & 0.05 & 0.00 & 0.05 & 0.00 & 0.06 & 0.00 & 0.06 & 0.00 \\
\hline Constant & 5.30 & 0.00 & 6.80 & 0.00 & 5.09 & 0.00 & 6.29 & 0.00 \\
\hline $\mathrm{L}(\beta)$ & \multicolumn{2}{|c|}{-1631.26} & \multicolumn{2}{|c|}{-609.93} & \multicolumn{2}{|c|}{-1598.09} & \multicolumn{2}{|c|}{-558.12} \\
\hline $\mathrm{R}^{2}$ & \multicolumn{2}{|c|}{0.61} & \multicolumn{2}{|c|}{0.85} & \multicolumn{2}{|c|}{0.62} & \multicolumn{2}{|c|}{0.86} \\
\hline$K$ & \multicolumn{2}{|c|}{7} & \multicolumn{2}{|c|}{11} & \multicolumn{2}{|c|}{10} & \multicolumn{2}{|c|}{15} \\
\hline$L L R$ & \multicolumn{2}{|c|}{2042.66} & \multicolumn{2}{|c|}{2125.62} & \multicolumn{2}{|c|}{2059.28} & \multicolumn{2}{|c|}{2146.28} \\
\hline$x_{0.05}^{2}$ & \multicolumn{2}{|c|}{-} & \multicolumn{2}{|c|}{$\begin{array}{c}9.49 \\
\text { (diff. } \mathrm{df}=4)\end{array}$} & \multicolumn{2}{|c|}{$\begin{array}{c}7.82 \\
\text { (diff. } \mathrm{df}=3 \text { ) }\end{array}$} & \multicolumn{2}{|c|}{$\begin{array}{c}15.51 \\
\text { (diff. } \mathrm{df}=8)\end{array}$} \\
\hline
\end{tabular}

\subsubsection{Direct effect of toll road construction on local road projects}

In the direct effect model, the variable "positive year gap" between the construction of the toll roads and the local roads has a positive value (0.16) in explaining local road projects. It indicates that local road projects tend to be realized after the construction of a toll road. The negative year gap variable shows a significantly negative value (-1.18). This, on the other hand, signifies that local road projects started before toll road construction tend to be realized close to the construction year of a toll road, apparently in anticipation of the effects of the planned toll road.

Moreover, constructed and planned local road projects tend to be located farther from the toll gates than national or provincial roads (which often actually contain the toll gates), explained by the positive and significant coefficient value of the distance to the toll gates (0.49). It is also strengthened by the result of a dummy variable for longer distances, which shows a positive value (7.46). The descriptive statistic shows that the average closest distance between non-local (national or provincial) road projects and the toll road gate is $2.9 \mathrm{~km}$ and the distance between local road projects and the toll gate is $3.5 \mathrm{~km}$. This shows that local road projects are located farther away from the toll gates, followed the hierarchy system of public roads as discussed in Section 4 about the study area. 


\subsubsection{Indirect effect of toll road construction on local road projects}

The indirect effect model represents urban development and characterized by the variables of industrial land use, residential land use and population changes. The construction of local road projects is found to be influenced by industrial land-use change, as it is shown in the indirect effect model (with a value of 0.54 ), although the variable is not identifiable in the composite model.

Changes in residential land use and population size between 2010 and 2015 can explain local road projects in the composite model (with values of 0.77 and 0.05 , respectively). On the other hand, population change between 2000 and 2010 has no impact on the models. This is caused by the fact that there is a population decrease in several cells in this period. On that account, we distinguished the positive and negative changes in population in that period. As expected, both new variables are significant to affect local road construction, as shown in the composite model. Increased population has a positive effect in the model and vice versa for the decreased population. We can, therefore, say that population growth is positively linked to the construction of new local roads.

These results support the findings of Cervero and Hansen (2002) and Levinson and Karamalaputi (2003) who also showed that population growth has a positive coefficient and is significant in inducing road investments in the United States. Our results are also in accordance with findings from previous studies (for instance, Aljoufie et al., 2013; Ji et al., 2014) which concluded that motorway development triggers urban growth within the vicinity of these motorways.

\subsubsection{Decision-making in local road projects}

The decision-making process is represented in the base model with technical and governance aspects. Technical aspects indicate the nature of the local road project, which can affect investment decisionmaking. The product of the spatial plan and the length of the project parameters is also to be positive (0.06). We can also hypothesize that local governments in Indonesia prioritize longer links construction which already included in the regional spatial plan. Using Norway case, Fridstrom and Elvik (1997) also observed that the lack of legal basis would reduce the odds of a project to be carried out. We also found that the government prefers to select expensive projects, indicated by the positive parameter of "investment cost per kilometer" (0.05). Bigger projects are perceived to have larger accessibility benefits, as well as greater political interest (Eliasson et al., 2015).

Furthermore, a coefficient of 4.27 for the interaction between the variable "new roads" and "travel time" implies that local government is likely to invest in the construction of new roads that mainly aim to reduce travel time. It is in agreement with the finding from Nilsson (1991) that decision-makers prefer to consider the project's consequences, such as travel time reduction directly, to settle public sector investments.

The coefficient for "urbanized areas" is negative (-5.43) in the composite model. It reflects that local government tends to invest in local roads located not in urban areas since it is already quite dense and connected enough or because land acquisition would be costly in such areas. This result is in line with several previous studies. For instance, Eliasson and Lundberg (2012) found that in Norway, the government's selection of road projects is skewed towards rural areas. Similarly, Fridstrom and Elvik (1997) obtained a negative coefficient for the variable "major city area" in the selection of road projects.

Governance aspects of the decision-making process are represented in the models by the projects' main objective(s), the involvement of non-local government and the spatial plan variables (which indicate whether the project has been stated in the long-term spatial plan or not). In the composite model, we found that the involvement of the central and provincial government affects local road projects negatively $(-8.31$ and -8.82$)$. This result is explained by the fact that that central government has to manage 
infrastructure development in the national level. Local roads are handled by local government on the municipal level. Involvement of upper-level government would indicate development of infrastructure to serve wider area and has a regional impact. The central government does occasionally invest in local roads, but it depends on the service area of the local roads and the benefits of a new link for regional developments. In such cases, the local governments have to submit a proposal to the central government.

\subsection{Arc elasticities}

Given our findings, it is interesting to examine elasticities with respect to continuous variables that are significant in the composite model. The elasticity indicates the responsiveness in the probability of having a local road project if the value of one specific variable is increased by a certain unit. We calculated elasticity for six significant variables, namely the construction year gap (both positive and negative values) between the projects and toll gates, distance to toll gates, residential land-use development, population change and investment cost per kilometer.

Table 4 gives the absolute value of aggregate elasticities for the composite model for increments in specific variables of $1 \%, 5 \%, 10 \%$, while other variables remain constant. It also displays the relative changes in the average probability $(\bar{P})$, which express the changes in the probability in percentage terms. The elasticities can take on both positive and negative values. Positive elasticities indicate the increase in the probability given the increase in the modified variable, and vice versa. It is important to note that the relationship between the probability of having a local road with the parameters should not be perceived as entirely linear. Higher elasticities can occur across some ranges and lower across others.

The positive and negative variables of the construction year gap have the highest elasticities. Modifications of "positive year gap" variable also produce the highest relative changes in the probability value. The negative elasticity of variable "negative year gap" indicates the decrease in the probability given the increase in the value of this variable. These variables, then followed by "distance toll gates" which its $1 \%$ increment resulted in a $0.11 \%$ increase in the probability to have a local road project.

Variable of "residential land-use development" has the smallest elasticity of all variables, which means that the probability of having a local road project is less sensitive to this variable. Furthermore, three variables which indicated population changes are more responsive than "residential land-use development," as a $1 \%$ increase in the population will increase the probability of having local road projects in the area by $0.08 \%$. Increasing population size corresponds to the increasing number of trips, and contributes to exhaustion of the existing road capacity, thus reducing the travel speed and total travel time. As Hansen and Huang (1997) and Cervero and Murakami (2010) also pointed out that population density is a major determinant of vehicle miles travelled in US cities.

Furthermore, the effect of project characteristics, such as investment cost cannot be ignored. The elasticity of "investment cost" indicates that an increment of $1 \%$ in the cost per kilometer raises the probability of having a local road by $0.11 \%$. It is important to note that cost per kilometer does not consider the number of lanes, and local projects have fewer lanes than national or provincial projects. Also, all projects in the database were funded, therefore the present model forecasts the probabilities of being funded as a local or national project. 
Table 4. Average Arc Elasticities

\begin{tabular}{|c|c|c|c|c|c|c|c|c|}
\hline \multirow[b]{2}{*}{ Modified variable } & \multirow[b]{2}{*}{ Mean } & \multirow[b]{2}{*}{ Unit } & \multicolumn{2}{|c|}{$1 \%$ Change } & \multicolumn{2}{|c|}{$5 \%$ Change } & \multicolumn{2}{|c|}{ 10\% Change } \\
\hline & & & $\bar{E}$ & $\begin{array}{c}\text { Relative } \\
\text { change } \\
\text { of } \bar{P}\end{array}$ & $\bar{E}$ & $\begin{array}{c}\text { Relative } \\
\text { change } \\
\text { of } \bar{P}\end{array}$ & $\bar{E}$ & $\begin{array}{c}\text { Relative } \\
\text { change } \\
\text { of } \bar{P}\end{array}$ \\
\hline Positive year gap & 13.22 & Year & 0.343 & $0.07 \%$ & 0.358 & $0.35 \%$ & 0.377 & $0.71 \%$ \\
\hline Negative year gap & 0.37 & Year & -0.266 & $-0.01 \%$ & -0.199 & $-0.03 \%$ & -0.146 & $-0.06 \%$ \\
\hline Distance to toll gates & 4.04 & $\mathrm{Km}$ & 0.113 & $0.02 \%$ & 0.115 & $0.11 \%$ & 0.118 & $0.22 \%$ \\
\hline Residential land-use development & 0.85 & $\mathrm{Ha}$ & 0.013 & $0.00 \%$ & 0.013 & $0.01 \%$ & 0.013 & $0.03 \%$ \\
\hline Population change (2010-2015) & 7.28 & Person & 0.078 & $0.01 \%$ & 0.079 & $0.07 \%$ & 0.080 & $0.14 \%$ \\
\hline Population increased (2000-2010) & 45.00 & Person & 0.046 & $0.01 \%$ & 0.047 & $0.04 \%$ & 0.047 & $0.08 \%$ \\
\hline Population decreased (2000-2010) & -2.04 & Person & -0.017 & $0.00 \%$ & -0.017 & $-0.01 \%$ & -0.017 & $-0.03 \%$ \\
\hline Investment cost per kilometer & 16.47 & Billion IDR & 0.107 & $0.02 \%$ & 0.109 & $0.11 \%$ & 0.112 & $0.22 \%$ \\
\hline
\end{tabular}

\section{Conclusions and discussion}

This paper examined the direct and indirect effects of toll road construction on local road projects in the Jakarta-Bandung region. The main contribution of this paper is the use of high temporal and spatial resolution to analyze ex-post toll case in developing countries, as well as combining statistical analysis, with spatially detailed data to perform a robust predictive model.

Our modelling results firstly show that existing and planned toll roads induce the development of local road projects both directly and indirectly. Local road projects tend to be developed in anticipation of the opening of the toll road and advocated by local governments to reduce travel time. The changes in residential area and population around the toll roads also induce local road construction. This finding strengthens the argument that it is necessary to separate direct and indirect effects of major road investments.

Secondly, with regard to methodology, we conclude that the models exhibit a reasonable explanatory power and that the direct effect model has a better goodness of fit than the indirect effect model. The addition of parameters related to toll roads and urban development, such as project and toll gate year gap, distance to toll gates, residential land use and population changes significantly improved the basic model to describe the decision-making of local road project constructions.

Finally, there are policy and planning implications which can be derived from this study. We have shown that toll road construction in the Jakarta and Bandung region affects local road investment, both directly and indirectly, through the changes in residential area and population. Economic appraisals of major transport investments in Indonesia and elsewhere might take into account induced demand effects but do not account for induced supply effects on local infrastructure. However, induced supply effects can influence traffic flows, accessibility levels and thus the economic and social impacts of major road investments.

In the Indonesian decentralized government system, local government has the full authority to carry out local road projects. They, thus, should synchronize local road plans with the national road plan and anticipate any effects due to the construction of major national roads, such as the emerging of new activities and the increasing population. The central government could take induced supply effects into account in economic appraisals of toll roads by conducting some sensitivity analysis.

Future research can improve these analyses by incorporating local road projects in a wider area (beyond the $18 \mathrm{~km}$ zone used in this study). Also, our data do not enable us to determine which projects will be realized and which ones will not, since our study only concerns road projects that had already 
been approved by the local government. There may be other factors, such as network-related variables (congestion, road capacity and current travel speed), as well as political agenda or national events that play a role in decision-making, but that are not part of our dataset and therefore were not captured by our models.

Furthermore, to be able to identify the indirect effect of toll road construction, it is essential to have reliable time series. For instance, the intervals of land use and population data should be consistent and small enough to be able to test the effect of different time periods on transport investment and vice versa. This might reveal feedback relationships between road transport investment and land-use changes which are not incorporated in our study.

\section{Acknowledgments}

This research was funded by The Royal Netherlands Academy of Arts and Sciences (KNAW), as a part of joint research project The local and regional dimensions in Indonesia's social and economic development. We thank the two anonymous referees whose comments helped to improve this paper substantially. 


\section{References}

Aljoufie, M., Zuidgeest, M., Brussel, M., \& van Maarseveen, M. (2013). Spatial-temporal analysis of urban growth and transportation in Jeddah City, Saudi Arabia. Cities, 31, 57-68. doi:http://dx.doi. org/10.1016/j.cities.2012.04.008

Avin, U., Cervero, R., Moore, T., \& Dorney, C. (2007). Forecasting indirect land-use effects of transportation projects. Washington, DC: American Association of State Highway and Transportation Officials. Retrieved from http://onlinepubs.trb.org/onlinepubs/archive/NotesDocs/25-25(22)_FR.pdf.

Banister, D., \& Berechman, Y. (2001). Transport investment and the promotion of economic growth. Journal of Transport Geography, 9(3), 209-218.

Baum-Snow, N. (2007). Did highways cause suburbanization? The Quarterly Journal of Economics, 122(2), 775-805.

Ben-Akiva, M. E., \& Lerman, S. R. (1985). Discrete choice analysis: Theory and application to travel demand (Vol. 9). Cambridge, MA: MIT press.

Bierlaire, M. (2017). Calculating indicators with Biogeme. Paper presented at the Choice Modelling in Environmental Research: Challenges, Applications and New Trends. September 25, University of Bern, Switzerland.

Boarnet, M. G. (1996). The direct and indirect economic effects of transportation infrastructure. Berkeley, CA: University of California Berkeley University of California Transportation Center. Retrieved from https://escholarship.org/uc/item/1506r290

Cervero, R., \& Hansen, M. (2002). Induced travel demand and induced road investment: A simultaneous equation analysis. Journal of Transport Economics and Policy (JTEP), 36(3), 469-490.

Cervero, R., \& Murakami, J. (2010). Effects of built environments on vehicle miles traveled: Evidence from 370 US urbanized areas. Environment and Planning A, 42(2), 400-418. doi:10.1068/a4236

Chi, G. (2010). The impacts of highway expansion on population change: An integrated spatial approach. Rural Sociology, 75(1), 58-89. doi:10.1111/j.1549-0831.2009.00003.x

Downs, A. (2000). Stuck in traffic: Coping with peak-hour traffic congestion. Washington, DC: Brookings Institution Press.

Duranton, G., \& Turner, M. A. (2011). The fundamental law of road congestion: Evidence from US cities. The American Economic Review, 101(6), 2616-2652.

Eliasson, J., Börjesson, M., Odeck, J., \& Welde, M. (2015). Does benefit and cost efficiency influence transport investment decisions? Journal of Transport Economics and Policy, 49(3), 377-396.

Eliasson, J., \& Lundberg, M. (2012). Do cost-benefit analyses influence transport investment decisions? Experiences from the Swedish transport investment plan 2010-21. Transport Reviews, 32(1), 29-48.

Forslund, U. M., \& Johansson, B. (1995). Assessing road investments: Accessibility changes, cost benefit and production effects. The Annals of Regional Science, 29(2), 155-174.

Fridstrom, L. (1999). Econometric models of road use, accidents, and road investment decisions. Volume II. Oslo: Institute of Transport Economics.

Fridstrom, L., \& Elvik, R. (1997). The barely revealed preference behind road investment priorities. Public Choice, 92(1-2), 145-168.

Ghani, E., Goswami, A. G., \& Kerr, W. R. (2012). Highway to success: The impact of the Golden Quadrilateral project for the location and performance of Indian manufacturing. Retrieved from https://dash.harvard.edu/bitstream/handle/1/13135314/ghani,goswami,kerr_highway-to-success.pdf?sequence $=1$

Goode, F. M., \& Hastings, S. E. (1989). The effect of transportation service on the location of manufacturing plants in nonmetropolitan and small metropolitan communities. In W. R. Gillis (Ed.), Profitability and mobility in rural America: Successful approaches to tackling rural transportation problems. University Park, PA: Pennsylvania State University Press. 
Hansen, M., \& Huang, Y. (1997). Road supply and traffic in California urban areas. Transportation Research Part A: Policy and Practice, 31(3), 205-218. doi:https://doi.org/10.1016/S09658564(96)00019-5

Ji, W., Wang, Y., Zhuang, D., Song, D., Shen, X., Wang, W., \& Li, G. (2014). Spatial and temporal distribution of expressway and its relationships to land cover and population: A case study of Beijing, China. Transportation Research Part D: Transport and Environment, 32, 86-96. doi:http://dx.doi. org/10.1016/j.trd.2014.07.010

Levinson, D., \& Karamalaputi, R. (2003). Induced supply: A model of highway network expansion at the microscopic level. Journal of Transport Economics and Policy (JTEP), 37(3), 297-318.

Mouter, N. (2017). Dutch politicians' use of cost-benefit analysis. Transportation, 44(5), 1127-1145. doi:10.1007/s11116-016-9697-3

Nellthorp, J., \& Mackie, P. (2000). The UK roads review—a hedonic model of decision making. Transport Policy, $7(2), 127-138$.

Nilsson, J.-E. (1991). Investment decisions in a public bureaucracy: A case study of Swedish road planning practices. Journal of Transport Economics and Policy, 56, 163-175.

Nyborg, K. (1998). Some Norwegian politicians' use of cost-benefit analysis. Public Choice, 95(3-4), 381-401.

Odeck, J. (1996). Ranking of regional road investment in Norway. Transportation, 23(2), 123-140.

Odeck, J. (2010). What determines decision-makers' preferences for road investments? Evidence from the Norwegian road sector. Transport Reviews, 30(4), 473-494. doi:10.1080/01441640903138640

Rephann, T., \& Isserman, A. (1994). New highways as economic development tools: An evaluation using quasi-experimental matching methods. Regional Science and Urban Economics, 24(6), 723-751. doi:http://dx.doi.org/10.1016/0166-0462(94)90009-4

Rinaldi, S. M., Peerenboom, J. P., \& Kelly, T. K. (2001). Identifying, understanding, and analyzing critical infrastructure interdependencies. IEEE Control Systems, 21(6), 11-25.

Train, K. E. (2009). Discrete choice methods with simulation: Cambridge, UK: Cambridge University Press.

WJP-MDM. (2013). Konsep awal Pengembangan Metropolitan Bandung Raya. Retrieved from http:// metropolitan.jabarprov.go.id/sources/download/paper/6f79c-06-konsep-awal-pengembangan-metropolitan-bandung-raya_juni-2013_a22.pdf 